\title{
A internacionalização do IEA
}

\author{
UMBERTO G. CORDANI
}

O SER ELEITO, pelo Conselho Universitário da USP em 1989, para o
Conselho Diretor do Instituto de Estudos Avançados da USP, eu não
tinha ideia da importância do IEA. Pouco sabia sobre a sua missão e o seu desempenho. Na época era eu diretor do Instituto de Geociências. Formado em Geologia, até então tinha cuidado de minha progressão acadêmica sempre dentro das Ciências da Terra. Como geocientista, tinha certa familiaridade com os outros ramos das Ciências Exatas, como Física, Química, Matemática, entretanto pouco sabia sobre o caráter, a dimensão e o alcance das Ciências Sociais e Humanas. Meu olhar sobre elas modificou-se muito com minha entrada no IEA. Através das reuniões do seu Conselho, tive a oportunidade de participar de discussões de riqueza intelectual extraordinária, sempre abrangentes e sem limites de temática, a respeito do pensamento contemporâneo e da vida científica, cultural, nacional, mundial. Campos novos se abriram para mim, novas visões de mundo. Interdisciplinaridade, transdisciplinaridade, sociedade global, economia integrada, história cultural, política internacional. Nunca mais fui o mesmo. $\mathrm{Na}$ época era diretor do IEA Jacques Marcovitch. Alfredo Bosi editava, desde o início do IEA, a revista do Instituto. Ambos marcaram fortemente minha vida acadêmica daí em diante.

No início dos anos 1990, eu presidia a União Internacional de Ciências Geológicas e pertencia ao Comitê Executivo do ICSU, o Conselho Internacional para a Ciência. Em consequência, com a questão ambiental a todo vapor, estava bastante familiarizado com as temáticas ambientais encaradas de maneira holística, o "nosso futuro comum". Ao mesmo tempo, participava dos preparativos para a Conferência das Nações Unidas para Ambiente e Desenvolvimento, a Rio-92, visto que o ICSU tinha a missão de preparar o capítulo a respeito da ciência para a primeira versão da "Agenda 21 ". Essa aproximação com os assuntos da sustentabilidade do planeta, aliada à experiência anterior advinda das Ciências da Terra, tornou natural minha inserção na Área de Ciências Ambientais do IEA, da qual fui coordenador, indicado pelo diretor Marcovitch. Esforcei-me em fazer prosperar os projetos do Instituto nessa área. Participei de muitas discussões com as mudanças climáticas, os desastres naturais, o papel das Ciências da Terra para a sustentabilidade. Acompanhei de perto o desenvolvimento das atividades do Projeto Floram, um dos mais bem-sucedidos do IEA. Nessa mesma época, colaborei também para organizar toda uma série de atividades relacionadas com 
a agenda internacional a respeito de desenvolvimento sustentável, e com a participação brasileira na Rio-92.

Em 1993, ao ser escolhido como sucessor de Marcovitch na direção do IEA, pelo reitor Fava, coube-me a enorme responsabilidade de conduzir o Instituto no quadriênio seguinte. Tive então a visão completa de uma instituição acadêmica sem alunos e sem docentes permanentes, que dependia da colaboração voluntária de docentes de todas as unidades da USP, e de um grande número de personalidades pertencentes a entidades externas. Verifiquei quão importante era a grife do IEA, e como era fácil obter a colaboração voluntária e frequentemente espontânea de todas as pessoas envolvidas. Verifiquei que o IEA situavase como uma espécie de "braço externo" da USP, ao conduzir suas discussões sempre no sentido de aproximar a Universidade com a sociedade.

Durante os anos de vínculo com o IEA, creio que minha contribuição principal tenha sido o esforço de internacionalizar as suas atividades. De início, pela aproximação com o ICSU e com a organização da Rio-92; em seguida, por meio das atividades da Área de Assuntos Internacionais, uma das mais importantes do IEA, que aliás já existia na época de minha primeira entrada no Instituto. Entendo que as ideias e as discussões ocorridas durante os eventos organizados pelo IEA nessa área acabaram incrementando as atividades internacionais da própria USP. Posteriormente tive também a oportunidade de favorecer o desenvolvimento dessas ideias, quando exerci a presidência da CCInt, a Comissão de Cooperação Internacional da USP, durante a gestão do reitor Marcovitch. Em 2004, no mandato do reitor Melfi, foi inaugurado na USP o Instituto de Relações Internacionais, o IRI, o qual dá guarida ao Gacint, o Grupo de Análise da Conjuntura Internacional, em cujas origens está justamente a Área de Assuntos Internacionais do IEA.

Guardo enorme afeto em relação ao Instituto de Estudos Avançados. Considero muito rico o vínculo que com ele mantive. Reconheço que ele ampliou substancialmente meus horizontes intelectuais. Foi um marco importante em minhas atividades acadêmicas. Abriu minha mente e mudou minha percepção de mundo. Mudou minha vida.

Umberto G. Cordani é professor do Instituto de Geociências da Universidade de São Paulo. Foi diretor do IEA no período 1993-1997. @- ucordani@usp.br.

Recebido em 19.9.2011 e aceito em 25.9.2011. 